Euskal ikerketen aldizkaria | Revue d'études basques |

Revista de estudios vascos | Basque studies review

$17 \mid 2013$

Numéro XVII

\title{
Literatura Unibertsala bildumaren bideak
}

\section{Miren Ibarluzea Santisteban}

\section{OpenEdition}

Journals

Édition électronique

URL : https://journals.openedition.org/lapurdum/2418

DOI : $10.4000 /$ lapurdum.2418

ISSN : 1965-0655

Éditeur

IKER

Édition imprimée

Date de publication : 1 octobre 2013

Pagination : 93-107

ISBN : 978-2-86781-409-9

ISSN : $1273-3830$

Référence électronique

Miren Ibarluzea Santisteban, «Literatura Unibertsala bildumaren bideak», Lapurdum [Linean], 17 | 2013,

Sarean emana---an 15 novembre 2015, kontsultatu 23 juillet 2021. URL: http://

journals.openedition.org/lapurdum/2418; DOI: https://doi.org/10.4000/lapurdum.2418

Ibarluzea M. | IKER 


\title{
Literatura Unibertsala bildumaren bideak ${ }^{1}$
}

\author{
MIREN IBARLUZEA SANTISTEBAN \\ Bordeaux 3
}

Literatura Unibertsala literatur itzulpenen bildumak 20 urte baino gehiagoko ibilbidea egin duenez gero, interesgarria deritzogu itzulpen-bilduma horren harrerari erreparatzeari. Bada, artikulu honetan, bildumaren deskribapena egiteaz gain, bildumak izandako eraginak eta islak zein izan diren azaleratzen saiatuko gara.

Literatura Unibertsala bildumaren ezaugarri nagusiak aztertzeaz eta bildumaren historia labur bat eskaintzeaz gain, bildumako itzulpenen egileen profilari begiratuko diogu. Halaber, liburu-azalez, kontrazalez, kreditu-orriez eta hitzaurreez zenbait ohar egin ondoren, bildumako obrei buruzko kritikak eta prentsan zein blogetan agertutako aipamenak laburbiltzen eta aztertzen saiatuko gara. Bestalde, bildumak irakurle-txokoetan, eskola-liburuetan eta entziklopedietan eta corpusetan duen presentziaz ere arituko gara.

Itzulpen-teoria garaikideen haritik, Literatura Unibertsala itzulpen-bildumak Euskal Literatur Sisteman duen lekua zein den deskribatzeko pausoa izan nahi luke artikulu honek. Lekuaz ari garenean, teoria sistemikoari jarraiki, kokaguneez ari gara, hau da, literatur instituzioaren barruan duen botereaz. Hala, itzulpenerako aurreikusitako helburuak zein ziren azaldu behar da, itzulpena nola aurkeztu den aztertu, eta azkenean, aurreikusitakoak bete

1.- 2012ko ekainaren 26an Udako Euskal Unibertsitateak eta EIZIE elkarteak antolatutako Literatura unibertsala itzultzen ikastaroan emandako hitzaldia jasotzen du artikulu honek. EHUko Euskal Hizkuntzalaritza eta Filologia masterrean Mari Jose Olaziregiren zuzendaritzapean itzulpen-kritikari buruz egindako master-tesiari segida ematen dion ikerketa-lanaren emaitza da. Har bitzate eskerrik beroenak lan honetarako datuak helarazi dizkiguten EIZIE elkarteko langileek, 111 akademiakoek eta irakurle-txokoetan akuilari ibiltzen diren Isabel Castillok eta Iban Zalduak. Halaber, testu honen zuzenketa- eta orrazketa-lanetan ibilitako Mari Jose Olaziregiri, Isabel Etxeberriari, Iñigo Rokeri eta Eneko Zuloagari eskerrik asko. 
direnetz frogatu, eta itzulpena onartzen denetz ikusi. Gideon Touryren metodologiari jarraituz gero (Toury, 2004), bide horretatik ez da soilik itzulpena oro har zer den aztertzen, ezpada itzulpena errealitatean zer den deskribatzen. Dudarik gabe, erregelak, arauak eta idiosinkrasiak existitzen dira itzulpengintzan, "Translation norms" izenekoak (Toury, 2004). Arauok aldatu egiten dira gizarte edo kultura batetik bestera. Touryren teoriei jarraiki, itzulpen arauak itzulpen errealen baliokidetza mailakatzen duten arauak dira. Hasierako arauak eta operazionalak bereizten dira, non hasierako arauak itzulpen-politikari lotzen zaizkion eta operazionalak, ostera, testuari berari eragiten diotenak diren. Arauok aztertzeko metodoa azaltzean testu-iturriak eta iturri estratestualak (formulazio semi-teorikoak eta kritikoak) aztertu behar dira (Toury, 2004). Hala, gure artikulu honetan berebiziko garrantzia izango dute itzulpenei lotutako paratestuek; zehazki, bildumaren inguruan argitaratutako artikuluek, kritika publiko zein akademikoak, bilduma jasotzen duten testuek, eta abarrek.

\section{1.- Bildumaren ezaugarri nagusiak eta historia}

\subsection{Bildumaren ezaugarri nagusiak}

Literatura Unibertsala bildumaren ezaugarri nagusietako bat ekimen instituzionala, publikoa, izatea da. Izan ere, Eusko Jaurlaritzak eta EIZIE Euskal Itzultzaile, Zuzentzaile eta Interpreteen Elkarteak egindako hitzarmenaren fruitua da. Garaiko behar bati erantzuteko asmoz, hainbat bilera egin zituzten bi erakunde horiek. Hala jasota dakar, hain zuzen ere, Lurdes Auzmendik Senez aldizkariko 7. zenbakian, elkartearen urteko balantzea egiten duenean. Hala, bide horretatik iritsi zen EIZIE elkartearen eta Eusko Jaurlaritzaren arteko hitzarmena. Hitzarmenean bertan azaltzen dira bildumaren oinarriak eta xedeak ${ }^{2}$ :

"Kultura Sailak eta EIZIEk

Azaltzen dute

1. Euskararen normalizazio bidean itzulpengintzan zein interpretazioarloan etengabe garatzen ari diren jarduerak onuragarriak izateaz gain, premiazkoak ere badira.

2. Itzulpengintza zein interpretazioa garatzeko ekintzak eta, halaber, Euskal Herrietan arlo horietan diharduten profesionalen sustapena bat datoz Kultura Sailak dituen helburuekin.

3. Atzerriko literatura euskaraz irakurtzeko aukera zabaltzen ari bada ere, munduan barreneko literatura klasikoaren gabezia nabarmena baino nabarmenagoa da euskaraz, eta horri aurre egiteko literatura unibertsalaren ondarea euskaratu eta argitara emateko plangintza ezinbestekotzat jotzen da.

4. LITERATURA UNIBERTSALA deritzan itzulpen-bilduma osatzeko oinarrizko irizpideak finkatu ziren 1989. urtean, Euskal Editoreen Elkarteak (EEE), Euskal Itzultzaile, Zuzentzaile eta Interpreteen Elkarteak (EIZIE) eta Eusko Jaurlaritzaren orduko Kultura eta Turismo Sailak 
hainbat bilera egin eta gero."

Ekimen instituzionala izateaz gainera, bildumaren ezaugarri garrantzitsua da itzulpenlehiaketa bidez esleitzen direla itzulpen-lanak. EIZIEk deitutako batzorde batek (EIZIE, Eusko Jaurlaritza, argitaletxea) izenburuen zerrenda hautatzen du. Izenburuen zerrenda badelarik, urtean-urtean, maiatz aldera, itzulgaien zerrenda kaleratu eta lehiaketarako deialdia egiten da. Deialdiari men eginez, itzultzaileek itzulgaien laginak prestatzen eta aurkezten dituzte. EIZIEk deitutako epaimahaiak laginak hautatu eta esleipena egiten du. Esleipena egiteko Jaurlaritzaren eta EIZIEren artean adostutako orri kopuruaren baremo bat dago. Deialdian orri gutxiago esleituz gero, bigarren deialdi bat egiten da. Gehiago eginez gero, berriz, Eusko Jaurlaritzarekin akordioren bat egiten da ${ }^{3}$. Esleipenerako irizpideak epaimahaiak ezartzen ditu.

Nabarmentzekoa da, argitaletxeren batek lehiaketarako zerrendako libururen bat argitaratu nahi badu, atera egiten dela lehiaketarako zerrendatik. Hala, izenburu jakin hori ez da bilduman jasotzen; izan ere, ekimen pribatuari lehiarik ez egitea hasiera-hasierako irizpidea da bilduman.

Itzultzailea aintzatestea da bildumaren ardatzetako bat. Aintzatespen hori, besteak beste, tarifetan islatzen da. Lehiaketaren oinarrietan jaso ohi dira tarifak, eta ordainsariak sorburu-hizkuntzaren araberakoak izaten dira4 .

Tarifa duinez gainera, oro har, literatur itzultzaile gehientsuenen aldarri dira, halaber, lana entregatzeko epeak bidezkoak izatea eta kontratu bat sinatzea. Epeei dagokienez, Literatura Unibertsala bildumaren kasuan, itzulpenak egiteko epea orri kopuruaren araberakoa $\mathrm{da}^{5}$. Kontratuaz denaz bezainbatean, itzultzaileak lana egin aurretik sinatzen du. EIZIEren eta itzultzailearen artekoa izaten da kontratua. Honela diote lehiaren oinarriek: "Esleipenaren ondoren, obra osoaren itzulpena zenbateko finko batean egiteko kontratua sinatuko dute EIZIEk eta itzultzaileak". Itzulpenaren egile-eskubideak errespetatuta, liburu forman argitaratzeko, 5 urterako edo 2.500 ale bitarteko eskubideak ematen dira. EIZIEk pasatzen dio lana argitaletxeari gero, baldintza berberetan. Horrek esan nahi du beste edozein ustiapen egiteko itzultzaileari baimena eskatu behar zaiola.

Bildumaren ezaugarritzat jo daiteke, halaber, zuzenketa-prozesu jakin bati jarraitzen zaiola. Itzultzailearen lana argitaletxeak izendatutako zuzentzaileak egiten du. Argitaletxearen eta itzultzaileen arteko desadostasun-egoera jasota dago lehiaketaren araudian, eta arbitrajemahai bat dago aurreikusita desadostasun-kasuetarako. Hala jasotzen da kontratuan ${ }^{6}$ :

3.- Adibidez, 2012an ez zen lehiaketarik izan, 201 ln bi urterako kopurua esleitu zen eta.

4.- Hauexek dira tarifak, orriko: gaztelania: 24 ; frantsesa, ingelesa, katalana, galegoa, portugesa, italiera: 27 ; gainerakoak: 30 . Itzulpena jatorrizko hizkuntza ez den beste batzuetatik egiten bada, sorburu-hizkuntzei dagozkien tarifen batez bestekoa erabiltzen da. Ordainketarako bi aukera egoten dira: hiru zatitan egindako ordainketa edo ordainketa osoa; lana amaitzean egitea.

5.- 125 orri - 6 hilabete; 250 orri - urtebete; $>250$ orri - proportzioan kalkulatzen da.

6.- Kontratuko pasarte hau EIZIE elkarteak helarazi digu. 
Itzulpenaren onargarritasun egoeragatik bi alderdien artean sor daitezkeen arazoak EIZIE Elkarteak izendatutako arbitraje-mahai batek konponduko ditu, eta bi alderdiak haren aginduetara bilduko dira.

\section{Itzulpenaren zuzenketak}

Argitaletxeak itzultzaileari zuzenketa proposamenak jakinarazi ondoren, horiek onartu ala ez onartu itzultzailearen esku geratuko da. Itzultzaileak dohainik egin beharko ditu zuzenketa horiek.

Liburua argitaratu baino lehenago egin beharreko proba-zuzenketak maketadun testuetan egingo dira. Probak zuzentzerakoan malgutasunez jokatuko bada ere, itzulpena argitaletxeari entregatu ondoren, itzultzaileak ezingo du pisuzko aldaketarik egin. Horrelakorik gertatuz gero, editorea ez dago behartuta inposarazi nahi zaizkion aldaketak egitera.

Bildumako aleak aurkeztea argitaletxearen ardura izaten da. EIZIEk eta Eusko Jaurlaritzak ere parte hartzen dute, eta itzultzaileak bertan izaten dira. Gehienbat Donostian izaten dira, eta liburuak emateko eta argitaratzeko epeak kontuan harturik, oro har binaka aurkezten dira. Tarteka, saio zabalagoak ere egin izan dira, bilduma osoari begira.

\subsection{Bildumaren historia laburra}

Arestian esan bezala, Literatura Unibertsala bildumak 20 urtetik gorako ibilbidea egin du. Hainbat arotan sailka daiteke ibilbide hori:

Lehenengo aroa: 1990 eta 2002 bitartean argitaratutako 100 liburuek osatzen dute . $^{7}$ Ibaizabal argitaletxeak plazaratu zituen. Bidenabar, nabarmentzekoa da argitaletxea aukeratzeko ere lehiaketa-prozedura baliatzen dela. Argitaletxea bera 1990ean hasi zen Ibaizabal gisa, eta batez ere eskolarako materialgintzan eta haur- eta gazte-literaturan espezializatuta dago ${ }^{8}$. Gaur-gaurkoz aro horretako liburuak eskuraezinak dira; baina, zenbait titulu Armiarma proiektuaren webgunean deskarga daitezke e-book gisa9 .

EIZIEren eskariz, Literatura Unibertsala bildumako lehenengo aroa bukatutakoan, Mari Jose Olaziregik eta Iñaki Aldekoak balorazio-artikulu bat idatzi zuten. Senez aldizkariaren 23. zenbakian dago argitaraturik. Labur esanik, artikulugileek nabarmentzen dute XIX. eta XX. mendeetako egileak eta lanak jasotzen direla soilik bilduman, alegia, modernitatea dela bizkarrezurra. Poesia gutxi ageri dela diote, eta egilez egileko bidea baztertu gabe, antologiak argitaratzeko proposamena egiten dute. Bestalde, zenbait hutsune zehazten dituzte, eta itzulgai zehatzen izenburuak proposatzen. Literatur kritikari eta irakasle biek egindako proposamenei men eginda, Literatura Unibertsala bildumako bigarren aroko zerrendan ageri dira titulu horietako hainbat.

Bildumaren bigarren aroa 2002 eta 2010 urte-tartean argitaratutako 52 liburuek osatzen dute. Kasu horretan, bildumako obrak kaleratzeko ardura Elkar eta Alberdania etxeena izan

7.- Liburuen zerrenda: http://www.eizie.org/Argitalpenak/Literatura_Unibertsala/OrainArte

8.- Ikus argitaletxeari buruzkoak: http://www.ibaizabal.com/argi aur.php

9.- Hauxe da webgunearen esteka: http://armiarma.com/liburu-e/ 
zen. Elkar eta Alberdania nor bere aldetik aurkeztu ziren lehiaketara, baina epaimahaiak proposatu zien koedizioan jardutea. Biek onartu zuten. Esleitzen ziren proiektuen arabera egiten zuten liburuen banaketa bi etxeek, eta nork bere etxean egiten zuen itzulpena helarazten denetik kaleratzen den bitarteko lana, betiere elkarren berri izanik eta argitalpen-plangintza denen artean koordinaturik.

Aro horretako balorazioa Iñigo Errastik bildu zuen Senez aldizkariaren 37. zenbakian. Balorazio hori hainbat eragileri bidalitako galdetegi baten emaitza da, eta erantzuleek, oro har, egokitzat jo zuten bildumaren egitasmoa. Aipatutako artikuluan dakarrenez, halaber, bildumak hasierako asmoak betetzen zituela uste zuten galdetegia erantzun zutenek. Itzultzaileei trebatzeko aukera eman dien bilduma dela aipatu zen dosierrean (itzultzaileek eurek ere bete zuten galdetegia). Itzulgaiei dagokienez, bildumak ikuspegi maskulino eurozentristatik harago joan behar lukeela ere adierazi zuten zenbait iritzi-emailek. Zenbaitek zalantzan jarri zituzten zenbait obraren eta autoreren presentzia. Bildumaren banaketari dagokionez, zenbaitek kezka agertu zuen ea ahalegin nahikoa egiten ote den bildumaren berri zabaldu eta obrak jendeari helarazteko. Kalitatearen inguruan, bigarren arokoen zuzenketa aurrekoena baino hobea dela aipatu zen. Lanak esleitzeko prozeduraren gainean iritzi kontrajarriak agertu ziren, eta zenbaitek salatzen zuten itzulpenik onena ebaluatu gabe, euskaraz ederren idatzi dena saritzen dela; alegia, ez ote zitzaion gehiago begiratzen hizkuntzaren edertasunari, itzulpenaren egokitasunari eta zorroztasunari baino (Errasti, 2009ez 37).

Literatura Unibertsala bildumaren bigarren aroko hitzarmena bukatu eta aro berrirako hitzarmena egin zenean, balorazio-aro bat etorri zen, Eusko Jaurlaritzak hala eskatuta. 2010ean, beraz, eten egin zen itzulgaien esleipena, eta bildumaren azterketarako eta sustapenerako jarduerak egin ziren. Eutsi egin zitzaion hitzarmenari, baina ordukoan EIZIEk bilduma sustatzeko ahalegin berezia egin zuen, bai eta hurrengo arorako bidea prestatu ere. Alde batetik, bilduma sustatzeko ekitaldiak egin ziren zenbait ikastetxetan eta zenbait literatur taldetan ${ }^{10}$. Beste alde batetik, 2010eko Itzultzailearen eguneko ekitaldi publikoa ere ildo beretik egin zen ${ }^{11}$ : bildumari buruzko bideo bat aurkeztu ondoren, Gotzon Egia EIZIEko kidea gidari zela, Iratxe Retolaza literatur kritikaria, Xabier Olarra itzultzaile eta editorea eta Lourdes Otaegi unibertsitateko irakaslea bildumaz aritu ziren. Egun hartan aurkeztu zen Literatura Unibertsala bildumaren kata$\operatorname{logoa}^{12}$. Aipagarria da ekitaldi hark isla handia izan zuela komunikabideetan: ohi baino gehiago izan ziren kazetetan, blogetan... argitaratutako artikuluak, balorazioak eta iritziak ${ }^{13}$. Halaber, sasoi berean abiatutakoa da Urrezko biblioteka izeneko bilduma ${ }^{14}$. Ikusirik bildumaren lehen-

10.- Bideoak eta materiala ikusgai daude EIZIEren webgunean. Literatura unibertsala sustatzeko ekitaldiak:

http://www.eizie.org/Elkartea/ikastaroak/Sustapena

11.- Itzultzailearen eguna 2010: http://www.eizie.org/Elkartea/ikastaroak/itzuleguna

12.- http://www.eizie.org/Argitalpenak/Literatura Unibertsala/katalogoa

13.- Ikus, esaterako: Karlos Zabalaren erreportajea, Berria egunkarian: http://paperekoa.berria.info/papera inprimatu.php?htmla=BERRIA\&urtea=y2011 \&hilabetea=m02 \&eguna=d20110218\&orria=p00020001; Miren Ibarluzearen erreportajea, Argia aldizkarian: http://www.eizie.org/Elkartea/ikastaroak/itzuleguna/ argia.pdf; Anartz Bilbaoren erreportajea Gararen Mugalari gehigarrian: http://www.eizie.org/Argitalpenak/ Literatura_Unibertsala/hemeroteka/mugalari20110204.pdf; edo Hedoi Etxartek idatzitako kritika: http:// www.argia.com/argia-astekaria/2279/literatura-unidirekzionala.

14.- Bildumari buruzko informazio gehiago: http://www.eizie.org/Argitalpenak/Berrargitalpenak 
biziko aroko 100 izenburuak eskuraezinak zirela, liburu horiek berrargitaratzeko plangintza diseinatu zuen EIZIEk 2010. urtean: 20 izenburuko sorta bat hautatu zen, bost urteko epean berrargitaratzeko ${ }^{15}$. EIZIE elkarteak jakinarazi digunez, hogei liburu horiek hautatzeko, hiru laguneko mahaia osatu zen: Inma Erreak, Estibaliz Ezkerrak eta Manu Lopez Gasenik hautatu zituzten itzulpenak, ondoko irizpide hauek gogoan harturik, besteak beste: obren beren garrantzia, irakaskuntzan erabilgarriak izatea eta gazteentzako erakargarritasuna. Urrezko biblioteka bildumako liburuen berrargitalpenerako, zuzenketa-prozesu berezi bati jarraitzen zaio: peritaje-mahai bat izendatu zen zuzenketarako. Mahaiak txosten bat prestatzen du eta zuzentzaileak horri jarraitzen dio; izan ere, asko dira azken urteetan euskararen normalizazioan emandako pausoak ${ }^{16}$. Azkenik, sustapen-aroko ekimena da, halaber, Literatura Unibertsala eskola-liburuaren berrargitalpena. EIMAko datu-baseetan egiazta daitekeenez, literatura unibertsalaren alorrean euskaraz argitaratu den eskola-material bakarra EIZIEk eta Erein argitaletxeak 2001ean plazaratutakoa da: Literatura Unibertsala. XVIII, XIX eta XX. mendeak. Ikusirik liburu hori agorturik zegoela, testu hori eguneratu, osatu eta argitaratzeko pausoak eman ziren ${ }^{17}$.

Gaur-gaurkoz Literatura Unibertsala bildumaren hirugarren aroan gaude. 201 ln abiatu zen, eta argitalpenaren ardura Erein, Alberdania eta Igela argitaletxeek dute. Hirugarren aroko itzulgaien zerrenda ( 80 bat obra) aditu talde bat bilduta egin zen: Bakartxo Arrizabalaga EIZIEko lehendakariaren zuzendaritzapean bildu ziren Jesus Cuenca, Lander Garro, Inazio Mujika, Marijo Olaziregi eta Lourdes Otaegi. Taldekideek kontuan hartu zituzten orain arte argitaraturiko egileen eta obren zerrenda, bildumak orain arte finkatu duen kanonaren gabeziak, bai eta euskaratutako literatura unibertsalaz eta bereziki dagokigun bildumaz argitaratutako zenbait azterketa eta gogoeta ere: esaterako, Manu Lopez Gaseniren "Euskal itzulpenen inbentarioa eta azterketa (1976-2008)"18, "Azken urteotako literatur itzulpenen azterketa" izeneko lan-saioa ${ }^{19}$ eta Iñaki Aldekoa eta Mari Jose Olaziregiren "Zenbait gogoeta Literatura unibertsala bildumaz"20.

\subsection{Zenbait ohar argitaratzaileez, hautaketa-prozesuez eta ebaluazioaz}

Puntu honetako datuei begiratuta, hainbat gogoeta egin daitezke. Batetik, nabarmena da argitaratzailearen profilak izan, baduela zerikusirik produktuan eta horren zabalkundean. Lehen aroko lanek zuzenketa-arazoak dituztela aipatzen da ebaluazioetan, eta argitaletxeak arloan esperientziarik ez izateak zerikusia izan dezake. Halaber, bilduma bera paper-ore bihurtu izanak agerian uzten du bildumari berari emandako garrantzia zein izan zen (biltegian lekurik ez eta stockean saldu gabe zeuden bildumako liburuak birziklatu egin ziren). Nolanahi den ere, denborak aurrera egin ahala eta bildumaren antolamenduan esperientzia hartu ahala, kudeaketa hobetu egin dela esan dezakegu.

Ibaizabalez gain, gerora, Alberdania, Elkar, Erein eta Igela ditugu bildumari lotuak.

15.- $\underline{\text { http://www.eizie.org/Argitalpenak/Berrargitalpenak/urrezkobiblioteka.pdf }}$

16.- Urrezko biblioteka bildumaren edizio-prozesuari buruzko artikulu bat bada Miren Ibarluzearen blogean: http://www.bizkaie.biz/blogs/bg4/?p=151

17.-Testuliburuari buruzko informazio gehiago: http://www.eizie.org/Argitalpenak/Literatura Unibertsala/ lit_unib_testuliburua

18.- http://www.eizie.org/Argitalpenak/inbentarioa/inbentarioa.pdf

19.- http://www.eizie.org/Argitalpenak/Senez/20091026/lansaioa

20.- http://www.eizie.org/Argitalpenak/Senez/20011101/aldekoa_olaziregi 
Hala, une honetan itzulpenak argitaratzen dituzten argitaletxe gehienek (berrienek ez beste guztiek) nolabaiteko lotura dute EIZIEk eta Eusko Jaurlaritzak sustatutako bildumarekin. Badirudi, gainera, itzulpenak argitaratzeko argitaletxeak elkartzeko joera bat badela, oro har, euskarazko literatur sisteman; bilduma honetatik kanpo, Erein eta Alberdaniak, esaterako, Batera saila dute elkarrekin.

Lehiaketan esleipenak egiteko epaimahaiaren irizpideak kontuan hartzen direla esan dugu; bada, hor ere argi geratzen da normalean itzulpenak neurtzeko objektibizazio-irizpiderik, baremorik edo taularik baliatzen ez dela. Itzulpengintzaren egoerarekin bat datorren aztarna da hori ere: itzulpengintzaren hezkuntza unibertsitarioan ere halakoak gertatzen dira, eta hala salatzen da, esaterako, CEATL elkarteak argitaratutako literatur itzulpengintzaren hezkuntzari buruzko txostenean ${ }^{21}$. Itzulpenaren ebaluaziotik bildumaren ebaluaziora igarota, elkarteak ebaluazioa aroz aro modu ezberdinean egin izanak ez du biderik ematen ebaluazioen arteko erkaketa sistematikoa egiteko. Nolanahi den ere, nabarmentzekoa da ebaluazioetan jasotakoei men egin izan dietela antolatzaileek, bai lehen aroko ebaluazioari, bai bigarren arokoari (antolamendua, zerrendak, zuzenketa-prozesua...).

\section{2.- Literatura Unibertsala bildumako itzultzaileen kopuruez eta profilez}

\subsection{Itzultzaileei buruzko datuak}

Literatura Unibertsala bildumaren lehenbiziko bi aroetan (bukatuta dauden aroak izanik, horiexek hartu ditugu azterketarako), alegia 152 aleen artean, 82 itzultzaile ditugu.

Hauexek dira bilduman ale gehien itzuli dituztenak: Koldo Biguri (8 ale), Jose Morales Belda (7), Josu Zabaleta (7), Xabier Mendiguren Bereziartu (7), Koro Navarro (6), Antton Garikano (5), Fernando Rey (5), Juan Garzia Garmendia (5), Karlos Zabala (4), Irene Aldasoro (3), Jon Muñoz (3), Juan Mari Mendizabal (3) eta Maria Garikano (3). Gainerako 69 itzultzaileek lan bat edo bi itzuli dituzte.

Nabarmentzekoa da, halaber, zenbaitetan itzultzaileak taldean aritu izan direla. Esku bitara itzulitako zortzi ale ditugu: Olga Mtz. de Marigortak eta Roberto Serranok itzulitako bi ale, Aintzane Atelak eta Miren Arratibelek itzulitako bi, Anjel Lertxundik eta J. Kruz Igerabidek itzulitako bat, Iñaxio Lopez de Aranak eta Martzelo Lopez de Aranak itzulitako bat, Juan Mari Arzalluzek eta Antton Olanok itzulitako bat eta Martxel Eguen taldeak egindako bat.

\subsection{Itzultzaileak eta sariak}

Literatura Unibertsala bildumako itzultzaileen profila euskarazko literatur sistemako errekonozimendu-eragileetako batekin lotuz gero (alegia, sariekin lotuz gero), ondoko erlazioa azaltzen da: 1997-2011 urte-tartean, 15 Euskadi Sari banatu zitzaizkien itzulpenei, eta horietako 10 Literatura Unibertsala bildumako itzulpenei. Nabarmentzekoa da, gainera, beste bost saridunek ere badituztela lanak Literatura Unibertsala bilduman (oro har, bat baino gehiago).

21.- Denon eskura dago dosierra: http://www.ceatl.eu/wp-content/uploads/2012/10/Formation-enquete-2012oct2012.pdf 


\subsection{Zenbait ohar itzultzaileen profilaz eta sariez}

Arestiko datuei erreparatuta, bildumak eta bertako itzultzaileek onarpen instituzionala badutela esan dezakegu (onartzen baldin badugu instituzioa dela sariemailea).

Oro har, euskal itzulpengintzan ibilbide luzea egin duten itzultzaileak dira Literatura Unibertsala bildumako itzultzaileak; bada, berek aitortzen dutenez (urtemugako bideoan, elkarrizketetan, ebaluazioetan), bilduma bera esperientzia-tailerra izan da haientzat. Nolabait, bildumak bidea eman die beren literatur itzultzaile-gaitasunak praktikan jartzeko eta zabaltzeko.

Hala ere, bildumako itzultzaileen artean badira itzultzaile hasiberriak ere, lehen itzulpena bilduman kaleratu dutenak. Praktikan ikus daitekeenez, hortaz, lehiaketa bidezko esleipena demokratikoa da: ez da nahierara erabakitzen zein izango diren itzultzaileak, laginei erreparatzen zaie; hala, hasiberrientzat erronka den arren, ez da ezinezkoa bildumako itzultzaile izatera iristea.

\section{Literatura Unibertsala bildumaren paratestuak aztertzen}

\subsection{Liburu-azalak, kontrazalak, kreditu-orriak eta hitzaurreak}

Bildumako hiru aroetako liburu-azalei eta kontrazalei begiratuz gero, itzulpena bera eta itzultzailea nabarmen agertzen direla esan dezakegu, bai eta, oro har, bildumaren diseinuak hainbat aldaketa jasan izan dituela ere, batez ere hasierako aroan.

Bildumaren lehen aroko liburuetan (alegia, Ibaizabalek argitaratutakoetan) hainbat diseinu ditugu. Hasierakoan hauxe da azalaren diseinuaren eskema: goialdean bildumaren izena ageri da (Literatura Unibertsala), beheraxeago egilearen izena eta obraren izenburua eta, azpialdean "Itzulpena: Itzultzailearen izena" eta argitaletxearen izena (Ibaizabal). Azpimarratzekoa da "itzulpen" hitza bera nabarmen agertzen dela azalean, eta itzultzailea ikusgarri dagoela azalean bertan. 1.-35. zenbakiek (1990-1993koek) ez dute azal-belarririk. 36. zenbakitik aurrerakoetan azaleko irudia kentzea eta azalari belarriak jartzea (36.-42. zenbakiak, 1993.-1994. urteetakoak) erabaki zen; ordukoetan "itzulpena" hitza desagertu egiten da azaletik, baina, halere, itzultzailearen izenak bertan dirau. Azal-belarrietan egilearen biografia eta obraren erreseina ageri dira. Kontrazalean ekimenaren babesleen logoak ditugu (Eusko Jaurlaritza, Ibaizabal eta EIZIE). Diseinuarekin gustura ez, eta azalaren diseinu-aldaketa egin zen 43.-100. Zenbakietarako. Ordutik aurrerakoetan hauxe da eskema: goialdean, bildumaren izena, egilearen izena, obraren izena eta itzultzailearena; azpialdean, argitaratzailearen izena. Belarrietako batean egilearen eta itzultzailearen biografia, eta bestean bildumako obren zerrenda. Kontrazalean, obraren erreseina eta ekimenaren babesleen logoak. Kreditu-orrietan jatorrizkoaren izenburua ematen da, bai eta jabetzari buruzko informazioa ere. Hurrengo orrialdean egilearen argazkia dugu, eta barruko azalean egilearen izena, obra, "Itzultzailea: itzultzailearen izena" eta logoak.

Bildumaren bigarren aroan, liburu-azal koloretsuagoak ditugu, ondoko eskemari jarraitzen diotenak: goialdean, bildumaren izena; azpian, obraren egilea eta itzultzailea; erdian, irudia eta obraren izenburua; azpialdean, argitaletxeen izena (Alberdania eta Elkar). Azalaren belarrietako batean, egilearen biografiaz gain itzultzailearena ere ageri zaigu; bigarren belarrian bildumako aleen zerrenda dugu. Kontrazalean lanaren erreseina eta ekimenaren babesleen logoak ditugu. Barruko azalean itzultzailearen izena emateko "Itzultzailearen izena, itzultzailea" formula erabiltzen da. Kreditu-orrietan ere jatorrizko izenburua ageri da, jabetza datuez gain. 
Urrezko Biblioteka bilduman, izenburua, egilea eta itzultzailea ematen dira azalaren goialdean, irudia azalaren erdialdean, eta argitaletxearen eta bildumaren izena azpian. Kontrazalean, obraren erreseina ageri da, eta, azpian, argitaletxearen, EIZIEren eta Eusko Jaurlaritzaren logoak. Azalaren belarrietako batean, egilearen biografiaz gain, itzultzailearena ere ageri zaigu. Bigarren belarrian bildumako obren zerrenda ematen da. Barruko lehenbiziko orrialdean, jatorrizko izenburua ere ematen da, eta horretan badagao "itzulpen" hitza, "Itzultzailea: itzultzailearen izena" gisa ematen baita itzultzailearen berri.

Hiru aroetako kreditu-orrietan ematen da itzultzailearen eta itzulpenaren berri. Hitzaurreei dagokienez, salbuespenak salbuespen, dagokion itzultzaileak idazten du lanaren hitzaurrea. Oro har, egileari buruzko jakingarriak eta lanaren literatur ezaugarriei buruzkoak aipatzen dituzte. Modu sistematikoan eta beti ez bada ere, hainbatek itzulpen-prozesuari buruzko jakingarriak ere ematen dituzte. Nolabait, kasu honetan, itzultzaileak berak hartzen du literatur kritikariaren rola.

\subsubsection{Kritika publikoa}

Literatura Unibertsala bildumako liburuei buruzko kritikak jasota daude EIZIEren webgunean $^{22}$. Lehen bi aroetako 152 aleetako 104 alek dituzte kritikak (EIZIEk abiaturiko Literatur itzulpena hedabideetan ekimenekoak batzuk, bestelakoen ekimenez egindakoak besteak, adibidez egunkarien ekimenez, eta kasu batzuetan bietakoak). Oro har, lanek kritika bat, bi edo hiru izaten dituzte. Prentsan kritika gehien izan dituzten lanak ondokoak dira: Zazpi urkatuak (6 kritika) Lubakia, Ez da erraza gizon on bat aurkitzea, Sumendiaren azpian, Loti ederrak, Sargazo itsaso zabala eta Abeslari burusoila (4na kritika dituzte).

Gaur egun abian den proiektuaren arabera, Literatura Unibertsala bildumako lan bakoitzak, gutxienez, kritika bat izango du (EIZIEren Literatur itzulpena hedabideetan ekimenaren bitartez).

2000-2009 urte-tarteko itzulpenen dibulgaziozko kritiken azterketako (Ibarluzea, 2011) ondorioak bat datoz bildumako aleen kritiken azterketarekin:

Obra agertu eta gutxira egiten dira kritikak; ez da denbora askorik igarotzen argitalpenetik kritika egiten den arte. Urtebete baino gehiago ez da igarotzen normalean. Badirudi euskarara ekarritako lanen kritika dibulgatiboa merkatuari lotu-loturik dagoela. Ematen du, nolabait, marketin-estrategia bat dela kritiken argitalpena, argitaratu berri diren lanak baino ez dira kritikatzen, eta testu zaharrak edo lehenago argitaratuak beste esparruetarako uzten dira. Testu klasikoak zein literatura unibertsaleko aleak betiereko irakurgai izan beharrean, ematen du iraungitze-data duten literatur lanak direla gurean, euskaraz sortu berri diren literatur lanen lehiakide, nolabait.

Azterketa horretako kritiken corpusa aztertzean ondoko galdera egin genuen guk: aipatzen al da zer ekimenen bidez egin den itzulpena? Eta horrek nolako eragina duen? Bada, Literatura Unibertsala bildumaren kasuan aipatu egiten da, bai. Nahiz eta oro har ezer gutxi aipatzen den agente eragileaz. Literatura Unibertsala bilduma aipatzen denean, alabaina, bilduma bera aipatzen da: ez, ordea, zein argitaletxek kaleratzen duen bilduma, ez eta nork 
bultzatzen duen ekimena ere (EIZIEk eta Eusko Jaurlaritzak).

Sarri aipatzen dira itzultzaileek egindako hitzaurreak. Nolabait esatearren, kritikari izaera onartzen zaie itzultzaileei, eta itzulpenaz diotena ez eze, "literaturaz" diotena ere aintzat hartzen zaie. Jazoera horrek handitu baino ez du egiten "itzultzaile=kritikari" adierazpenaz genuen susmoa. Izan ere, batez ere Literatura Unibertsala bildumako liburuen kasuan, itzultzailea bera da lanaren hitzaurrea idazten duena, nolabaiteko kritika egiten duena, jatorrizko sistemako datuen zein itzulpen-prozesuaren berri emanez. Aztertzekoak lirateke aipatu bildumako sarrerek zer duten kritikatik eta zein itzulpen-arau lantzen dituzten.

Jatorrizko hizkuntzaz eta xede-hizkuntzaz denaz bezainbatean, nabarmendu dezagun oso gutxitan aipatzen dela obren jatorrizko hizkuntza kritiketan. Xede-hizkuntza, ordea, askotan ematen da. "Euskaratu" zein "euskarara ekarri" moldeak erabilita, adibidez, itzulpenaz gain xede-hizkuntzaren berri ere ematen ari gara. Halaber, garrantzi berezia ematen zaio xedehizkuntza egokia erabiltzeari, eta hori normalizazio-egoerarekin lotu daitekeelakoan gaude. Zenbaitetan, gainera, esplizituki lotzen dira itzulpena eta normalizazioa, batez ere lehenago ere itzulita zeuden lanak berrargitaratu direnean eta hizkuntza aldaketak ageri direnean.

\subsubsection{Prentsa, blogak eta webguneak}

Literatura Unibertsala bildumak euskal prentsa idatzian izandako isla aztertzeko, Berria, Deia, El Correo eta Diario Vasco egunkarietako webguneak arakatu ditugu², kazeten webguneetako bilaketa-eremuan "Literatura unibertsala", "Literatura unibertsala bilduma" eta "Literatura \& EIZIE" bilaketak eginez.

Bada, bilaketaren emaitzak aztertu ondoren, ondokoa nabarmendu daiteke: oro har, prentsaurrekoen ostean eta urteurrenen harira sortzen dira Literatura Unibertsala bildumari buruzko berriak kazetetan. EIZIE elkarteak bideratutako eta bidalitako prentsa-oharrak dira kazetetan agertzen direnak, baina ez dira sistematikoki argitaratzen. Prentsan, Literatura Unibertsala bildumari arreta handiena jartzen dion kazeta Diario Vasco da (betiere azterketa honetarako bildu ditugun emaitzen arabera); ez bakarrik maiztasunean, ezpada baita informaziomotari dagokionez ere: EIZIEtik bideratutako berriez eta kritikez gain, lekua egin izan diete aipatu kazetan itzultzaileen elkarrizketei eta iritzi-artikuluei.

Egunkariez harago, sarean diren webgune eta blog batzuetara ere jo dugu, Literatura Unibertsalak bertan duen agerpena aztertzeko. Ondoko webgune eta blog hauek ikuskatu ditugu (denak ere euskal kulturari eta literaturari leku nabarmena ematen dieten guneak dira, kultur eragileenak, literatur sareenak, idazleenak, kritikarienak...): Hitzen uberan, Boligrafo gorria (Gorka Bereziartua), Alua Mundua (Hasier Etxeberria), Ardi txikia beti bildots (Miren Ibarluzea), Nontzeberri, Eibar.org webguneko blogak (Markos Zapiain, Xabier Mendiguren Elizegi, Julen Gabiria, Sareinak, Volgako Batelariak...), Esporak, Bazka (Koldo Izagirre), Zuzeu, Bizkaie. biz, Sustatu, Xerezaderen artxiboa, Idazkola (Iñigo Roke), Elearazi ${ }^{24}$. Kasu honetan ere blogaren edo webgunearen bilaketa eremuan "Literatura unibertsala", "Literatura unibertsala bilduma"

23.- Azterketa egindako sasoian Gara egunkariaren arakatzailean arazoak izan ziren bilaketak egiteko orduan. Bilaketak 2012ko maiatzean eta ekainean egin ziren.

24.- Bilaketak egiteko aukerarik eman ez eta hauexek geratu dira aztertu gabe: Beñat Sarasolaren bloga, Txuma Murugarrenen bloga, Habitat (Katixa Agirre) bloga, Bernardo Atxagaren bloga eta Faroa (Joxe Aranzabal). 
edo "Literatura \& EIZIE" bilaketak egin dira. Bilaketaren emaitzak aztertuta, ondokoa ondorioztatu dugu: oro har, EIZIEk bidalitako albisteen harira moldatzen dira postak, baina ez modu sistematikoan. Lanak esleitzeko deialdiaren berri modu sistematikoan ematen duen bakarra, esaterako, Sustatu webgunea da. Itzulpenarekin edo literaturarekin lotura zuzena dutenek baino ez dute bilduma modu zehatzagoan aipatzen: zuzenketak direla eta, esperientzia pertsonala dela eta, sustapena egin behar dela... Garrantzi handia eman zaio Susa argitaletxeak bildumako hainbat lan sareratu izanari. Irakurketa gomendagarri gisa agertzen da oro har bilduma aditu/arituen blogetan. Baina, esaterako, Hasier Etxeberriak bere blogean gazte batek eskoletan irakurri beharreko 10 liburuen zerrendaz galdegiten duenean, aipatzen diren 52 liburuen artean bi baino ez dira itzulpenak ${ }^{25}$. Oro har, esan daiteke itzulpenaren inguruko "aritu/aditu" kolektibotik kanpo, ez dela bildumaren berri jasotzen.

\section{Literatura Unibertsala bilduma hiztegietan eta corpusetan}

Wikipedia entziklopedia birtualera jo eta aurrekoetan bezala Literatura Unibertsala bildumari buruzko aipamenik ba ote den aztertuta, 19 aipamen agertzen dira (batez ere obrei eta egileei buruzko sarrerak dira, non euskarazko itzulpena aipatzen den). Bildumako lanen, itzultzaileen, egileen... sistematikotasunik ez da ageri, eta alde handia dago sarrera batetik bestera.

Auñamendi entziklopediaz denaz bezainbatean, Literatura Unibertsala bilduma zenbait itzultzaile/idazleren biografietan agertzen da; hain zuzen ere, Imanol Unzurrunzaga, Juan Garzia, Koro Navarro, Julen Gabiria eta Gerardo Markuletarenean. Bestalde, euskal literaturako sariketei buruzko sarreran eta argitalpenen historiari buruzkoan ere egiten da bildumaren aipamena ${ }^{26}$.

Euskaltzaindiaren Literatur terminoen hiztegian ez dago itzulpenari lotutako sarrerarik, hortaz, ezta Literatura Unibertsala bildumari buruzkorik ere.

Entziklopedietan eta hiztegietan ez eze, corpusetan ere agerkari izaten da itzulpena. Ereduzko Prosa Gaur izan dugu aztergai ${ }^{27}$, eta Literatura Unibertsala bilduma bertan da. 20002006 bitarteko 287 liburu daude Ereduzko Prosa Gaur corpusean ${ }^{28}$, eta Literatura Unibertsala bilduma corpuseko liburu-kopuru osoaren \% 11,84 da (alegia, 287 liburutik 34 LU bildumakoak dira). Liburu guztien arteko 105 itzulpenak dira; hortaz, corpusaren \% 36 itzulpena da. 105 itzulpen horietatik 34 dira LUkoak. Corpusean ageri diren itzulitako lanen (saiakerak barne, kontuan hartu gure bilduman literatura besterik ez dela) \% 32 bildumakoak dira. Aipatutako denbora-tarte horretan Literatura Unibertsala bilduman 42 liburu atera ziren, tarte horretako 28 daude zerrendan (bai eta beste data bateko 6 ere), erdia baino gehiago, beraz.

25.- Hemen post jakin horren esteka: http://zuzeu.com/blogak/alua-mundua/2007/11/29/zezenaren-adarretako-liburu-guztiak/

26.- http://www.euskomedia.org/aunamendi/73769 eta http://www.euskomedia.org/aunamendi/27080

27.- http://www.ehu.es/euskara-orria/euskara/ereduzkoa/

28.- Ereduzko Prosa Gaur corpusa sarean dago kontsultagai: http://www.ehu.es/euskara-orria/euskara/ereduzkoa/laguntza.html 


\section{Bildumaren hartzaileak: irakurle-txokoak eta eskola}

\subsection{Bilduma irakurle-txokoetan}

Ez da erraza izaten irakurketa-liburuen helarazpen maila neurtzen. Salmentak azter litezke, noski, baina liburu bat saltzeak ez du esan nahi liburu hori irakurtzen denik. Are gehiago, bilduma honetako lehenengo aroko aleak eskuraezin egoteak ez du esan gura denak saldu zirenik (biltegian lekurik ez eta paper ore bihurtu ziren). Hala, hemen irakurle-taldeetara jo dugu; izan ere, irakurle-lagin gisa fidagarria da irakurle-txokoetako irakurleen taldea: hilean behin bildu egiten dira liburuari buruzko solasaldian, eta, hor bai, segurua izaten da liburua irakurri izana.

Hona hemen hainbat literatur klubetan landutako liburuen inguruko datuak itzulpenei dagokienez:

\begin{tabular}{|l|l|l|l|l|l|}
\hline Taldea & $\begin{array}{l}\text { Zerrendako } \\
\text { liburuak }\end{array}$ & $\begin{array}{l}\text { Zerrendako } \\
\text { itzulpenak }\end{array}$ & $\begin{array}{l}\text { LU } \\
\text { bildumakoak }\end{array}$ & Itzulpenak (\%) & $\begin{array}{l}\text { LUko itzulpenak } \\
(\%)\end{array}$ \\
\hline Basauri & 7 & 1 & 0 & $\% 14,3$ & $\% 0$ \\
\hline Bilbo & 7 & 1 & 0 & $\% 14,3$ & $\% 0$ \\
\hline Zumaia & 7 & 1 & 0 & $\% 14,3$ & $\% 0$ \\
\hline Larrabetzu & 8 & 0 & 0 & $\% 0$ & $\% 0$ \\
\hline Getaria & 9 & 2 & 1 & $\% 22,2$ & $\% 50$ \\
\hline Bermeo & 12 & 4 & 0 & $\% 33,3$ & $\% 0$ \\
\hline Segura & 13 & 0 & 0 & $\% 0$ & $\% 0$ \\
\hline Donostia & 16 & 5 & 0 & $\% 31,3$ & $\% 0$ \\
\hline Meatzaldea & 19 & 2 & 0 & $\% 10,5$ & $\% 0$ \\
\hline Zumarraga & 22 & 0 & 0 & $\% 0$ & $\% 0$ \\
\hline Igorre & 23 & 5 & 0 & $\% 21,7$ & $\% 0$ \\
\hline Iurreta & 42 & 15 & 2 & $\% 35,7$ & $\% 13,3$ \\
\hline Durango & 49 & 16 & 2 & $\% 32,7$ & $\% 12,5$ \\
\hline Markina & 52 & 18 & 0 & $\% 34,6$ & $\% 0$ \\
\hline Gasteiz & 90 & 36 & 14 & $\% 40$ & $\% 38,9$ \\
\hline
\end{tabular}

Taulako datuei begiratuta, Gasteizko taldea da aztertutakoen artean literatur itzulpen gehien irakurri dituena. Iban Zaldua idazleak akuilatzen du taldea. Hona hemen 2012ko ekainean Literaturiak (Literatura eskolaren eta Larrabetzuko Udalaren ekimena) eta EIZIEk "Idazlearen eta irakurlearen artean, itzultzailearen itzala" mahai-inguruan gaiari buruz esan- 
dakoak ${ }^{29}$ : taldekideen iritziak kontuan hartzen baditu ere, bere hautua izaten da liburuen zerrenda. Zalduak aipatu zuenez, hasieratik hautatu izan ditu itzulpenak, eta itzulpenen presentzia handitu egin da taldearen ibilbidean. Zalduaren hitzetan, azken urteotan sortutako argitaletxeen jardunean ere gauza bera islatzen da. Alabaina, itzulpenei buruzko solasaldietara taldekide gutxiago agertzen zirela aitortu zuen: \% 40 inguru jaisten da parte-hartzaileen kopurua. Idazlea ez bertaratzeak jaitsiera hori baldintza dezakeela aipatu zuen, bai eta beste faktoreren batek ere: euskal idazleek errazkeriara jotzeak edo diglosia-egoerak. Bestalde, Zalduak aipatu zuen bere klubaren helburua literatura lantzea dela, eta ez idazleen erakustoki bihurtzea. Itzultzailea ez omen dute modu sistematikoan gonbidatzen solasaldietara, arrazoi ekonomikoak eta lotsa direla medio (lotsa, irakurle gutxiegi agertzen delako saiora).

\subsection{Literatura Unibertsala bilduma eskoletan}

\subsubsection{Literaturaren irakaskuntza eskoletan}

Idurre Alonso ikertzaileak literaturaren irakaskuntzari buruzko ikerketan esaten digunez (Alonso, 2010), irakaslearen hautuaren mendekoak dira Hego Euskal Herriko eskolasistemako irakurgaiak; hala, ikasleen gustuari eta testu ulerterrazei ematen zaie lehentasuna, irakurgaien balio literarioaren egokitasuna alde batera utzita. Irakurgaien izaerari buruz hiru ezaugarri aipatzen ditu Alonsok:

Lehen ezaugarria literatur generoaren inguruko irizpiderik ez egotea da; hala, aztertutako ikastetxeetan eleberriak dira irakurgai gehienak.

Irakurgaien izaerari buruzko bigarren ezaugarria itzulpenen urritasuna da. Honela dio, hitzez hitz, Alonsok:

"Bigarren ezaugarria urteko irakurgaietan itzulpen-lanek duten leku urria da; irakasgaia bideratuta dago literatura nazionala transmititu eta irakurtzera, eta ondorioz, euskaraz sortutako liburuetara mugatzen dira irakurketarik gehienak".

(Alonso, 2010: 137)

Ezaugarrien arteko hirugarrena sariketei dagokie: Alonsoren ikerketaren arabera, obrek jasotako sarien eragina hauteman daiteke eskoletako irakurketetarako hautuetan: hamar irakurgaitik lauk jaso dute Espainiako Kritika Saria.

Ondorio gisa, Alonsok adierazten du "euskal literaturaren irakaskuntzan ez dela antzematen irizpide pedagogikoetan oinarritutako sailkapenik" (139. or.). Halaber, ikerketak iradoki gisa, zera nabarmendu daiteke: "Eskolak erreproduzitu egiten dituela egon dauden literatur hierarkiak" (139. or.).

\subsubsection{Literatura Unibertsala bilduma testuliburuetan}

Alonsoren esanak osatzeko asmoz, eta Literatura Unibertsala bildumak eskoletako hi- 
zkuntza eta literaturako testuliburuetan duen isla aztertu nahirik, Batxilergoko hainbat testuliburu arakatu ditugu.

Jakin badakigu Hizkuntza eta Euskal Literatura lantzen dela Batxilergoan (Literatura Unibertsala gaia hautazkoa da). Alabaina, itzulpenen hizkuntz kalitatea ereduzkotzat jotzen den aldetik, eskoletan eredu gisa agertzen ote den aztertu gura izan dugu.

Hauek dira arakatutako testuliburuak:

- Euskara eta Literatura 1 DBHO (Batxilergoa), Ibaizabal, 1997, 331 or.

- Euskara eta Literatura 2 DBHO (Batxilergoa), Ibaizabal, 1998, 279 or.

- Hizkuntza eta Literatura 1 (Batxilergoa), Giltza, 2000, 263 or.

- Hizkuntza eta Literatura 2 (Batxilergoa), Giltza, 2001, 261 or.

- Euskara eta Literatura 1 (Batxilergoa), Elkar, 2004, 382 or.

- Euskara eta Literatura 2 (Batxilergoa), Elkar, 2005, 385 or.

- Baikor 1 (Batxilergoa), Euskara eta Literatura, Jakintzaren Etxea proiektua, Zubia, 2009, 237 or.

- Baikor 2 (Batxilergoa), Euskara eta Literatura, Jakintzaren Etxea proiektua, Zubia, 2009, 247 or.

- Komunikazioa I eta II, Ibaizabal, i.bai hi proiektua, 2010

- $\quad$ Ulermenaren bidean I eta II, Ibaizabal, i.bai hi proiektua, 2011

Ibaizabalen 1997ko testuliburuan Literatura Unibertsala bildumako Birjina eta ijitoa (D.H. Lawrence) eta Kali Lepamoztua (Marguerite Yourcenar) lanetako bi aipu daude, biak ere lotura semantikoei buruzko atalean (67. or.). Aditz sintagmaren egiturari buruzko atalean ( 72 . or.), Oscar Wilden Lord Arthur Savile-ren krimena lanaren zatitxo bat dugu. "Zerbait izugarria gertatu behar da herri honetan, Gabriel Garcia Marquez (Joseba Sarrionandiak itzulia)" irakur daiteke, narrazio-testuen egiturari buruzko atalean, eta "Zer dakizu honetaz?, Nazim Hikmet, itzultzailea: Gabriel Aresti” aditzari buruzko atalean (124. or.). Batxilergoko bigarren mailako liburuan, komunikazioari buruzko erdal saiakeren itzulpen-laginak baino ez ditugu: Qué pasa en el mundo, Juan Luis Cebrián; Medios de comunicación social. Teoría y práctica en Estados Unidos y en el mundo, John Lee, John Merrill, Edward Jay Friedlander; eta Historia de la comunicación, Raymond Williams.

Argitaletxe bereko testuliburu berriagoetan, 2010 eta 2011koetan, ez dago itzulpenlaginik.

Gauza bertsua gertatzen da Giltza eta Zubia argitaletxeen testuliburuetan.

Elkar argitaletxearen testuliburuetan, 1. mailako liburuan 2 itzulpen txatal agertzen dira: Matilda liburutik bat (251. or., estimu- eta erdeinu-seinaleak eta hitzak bilatzeko ariketan), eta La ciudad automática (J. Camba) liburutik bestea (338. or., deskribapenak zer sentsazio sorrarazten duen galdetuz).

Aurreko datuei erreparatuz gero, itzulpen-laginek testuliburuetan duten agerpen-urritasunaz ohar gaitezke. Izan ere, Ibaizabal argitaletxeko hasierako liburuetan baino ez dira Literatura Unibertsala bildumako itzulpen-txatalak agertzen (garai hartan argitaletxe horrexek argitaratzen zuen bilduma). Nabarmentzekoa iruditzen zaigu, halaber, euskarazko itzultzailearen berri hura itzultzailea bera euskal idazlea denean baino ez dela ematen. 


\section{6.- Ondorioak}

Bukatzeko, ondorio gisa, laburbil dezagun Literatura Unibertsala bildumari buruz egin dugun azterketak emandakoa. Bilduma sortu zenetik bertatik, itzulpen literarioa eta literatur itzultzaileak sustatzea izan du helburu, eta kalitatezko testugintza bermatzea. Bada, badirudi helburu bi horiek betetzen dituela bildumak. Alabaina, bildumak ez du nahi besteko zabalkunderik: irakurleen artean eta zenbait esparrutan ikusgaitza da oraindik ere; alegia, bilduma goretsi egiten bada ere, praktikan eta eredu zabal gisa ez da sarri baliatzen.

Nolabait, bildumak badu halako funtzio normalizatzaile bat; hizkuntzaren normalizazioan eta langintzaren normalizazioan eragin duela esan daiteke. Bildumaren funtzio didaktikoan eta aisialdiko irakurketakoan, baina, ez da oraindik nahi beste aurreratu.

Azkenik, hutsuneak betetzeaz denaz bezainbatean (hala aipatzen baita bildumaren sorrera-testuan), badirudi literatura unibertsal kanonikoaren hutsunea txikiagotzen lagundu duela. Baina eztabaidagai izan daiteke hutsunearen definizioa bera. Izan ere, hutsunea nork definitzen duen, halako fruitua eta erantzuna jasotzen da. Instituziotik instituziora egindako bilduma dela esan genezake (hala igartzen da, kasurako, sariketetan eta bildumaren aipamenetan); baina argi dago ikastetxeetan, irakurleen artean, etab. ez dela literatur molde honetako lanik eskatzen: balirudike euren literatur corpusean ez dela gisa honetako lanik falta, eurentzat ez dela hutsunerik.

\section{Erreferentziak}

Aldekoa, Iñaki \& Olaziregi, Mari Jose. 2001. Zenbait gogoeta Literatura Unibertsala bildumaz. In Senez 23. /Online: http://www.eizie.org/Argitalpenak/Senez/20011101/aldekoa olaziregi/

Alonso, Idurre. 2010. Erdigune literarioak irakaskuntzan. Bilbo: Euskal Herriko Unibertsitateko Argitalpen Zerbitzua.

Auzmendi, Lurdes. 1988. Euskal Itzultzaile, Zuzentzaile eta Interpretarien Elkartea. In Senez 7. /Online: http://www.eizie.org/Argitalpenak/Senez/19890130/auzmendi/

Errasti, Iñigo. 2009. Literatura Unibertsala bildumaren ebaluazioa. ELI dosierra. IN Senez 37. /Online: http://www.eizie.org/Argitalpenak/Senez/20091026/errasti/

Ibarluzea, Miren. 2011. Literatur itzulpenaren kritika. Lehenengo pausoak: dibulgazio-kritiken azterketa. Bilbo: Labayru ikastegia.

Toury, Gideon. 2004. Los estudios descriptivos de traducción y más allá. Metodología de la investigación en estudios de traducción. Madrid: Catedra. 
